Annals of Plant and Soil Research 23(3): 319-323 (2021)

https://doi.org/10.47815/apsr.2021.10077

\title{
Combining ability analysis for seed yield and its attributes in Indian mustard [Brassica juncea (L.) Czern and Coss]
}

\author{
D.A. PATEL ${ }^{1}$, D.K. PATEL ${ }^{2}$, J.R. PATEL ${ }^{3}$, P.J. PATEL ${ }^{4}$ AND A.B. PATEL ${ }^{5}$ \\ Department of Genetics and Plant Breeding, C. P. College of Agriculture, Sardarkrushinagar Dantiwada Agricultural \\ University, Sardarkrushinagar, Gujarat, India \\ Received: April, 2021: Revised accepted: June, 2021
}

\begin{abstract}
The experimental material comprised of forty eight genotypes consisting of five Mori based CMS lines and seven Mori based fertile lines crossed in line $x$ tester mating design. The resultant thirty five hybrids along with their twelve parents and standard check (GDM 4) were evaluated in randomized block design at CastorMustard Research Station, Sardarkrushinagar Dantiwada Agricultural University, Sardarkrushinagar during, rabi 2018-2019. The analysis of variance for combining ability revealed that variance due to gca was significant for all the characters except number of seeds per siliqua, seed yield per plant and 1000 seed weight. Whereas, variance due to sca was significant for all the traits. This indicates significant contribution of hybrids for specific combining ability variance component. The ratio of $\sigma^{2} g c a / \sigma^{2} s c a$ below than unity for days to maturity, siliqua length, number of seeds per siliqua, seed yield per plant, 1000 seed weight and oil content which suggested greater role of non-additive gene action in the inheritance of these traits. Among the parents, female SKM 9928 and Kranti were good general combiner for seed yield per plant, total number of branches per plant and total number of siliquae per plant. Whereas, male parent Mori ' $R$ ' 1-18 was good general combiner for seed yield per plant, total number of branches per plant and total number of siliquae per plant. Best three hybrids which possessed significant positive SCA effects for seed yield per plant were SKM 301 x SKM 303, SKM 9928 x Pusa Agrani and Kranti x Mori 'R' 1-18.
\end{abstract}

Keywords: Line x Tester, Combining ability, gene action, Indian mustard

\section{INTRODUCTION}

Indian mustard belongs to family Brassicacae and genus Brassica, popularly known as rai or raya. Indian mustard or brown mustard [Brassica juncea (L.) Czern \&Coss] is a natural amphidiploid $(2 n=36)$ of Brassica rapa $(2 n=20)$ and Brassica nigra $(2 n=16)$. Mustard is largely self pollinated but certain amount $(<18.7 \%)$ of cross pollination may take place. Indian mustard is mainly used for extraction of oil. Seed of Indian mustard contain 38 to 40 per cent oil and is mainly utilized for human consumption throughout Northern India for cooking as well as frying purpose. Besides, its oil also serves as an important raw material for industrial products like soap, paints, lubricants etc. Its oil cake is rich in protein but due to its high glucosinolate content it is not suitable for animal feed. Combining ability analysis is one of the powerful tools to test the value of parental lines to produce superior hybrids and valuable recombinants (Singh et al., 2013). Further, for developing better genotypes through hybridization, the choice of suitable parents is of great concern. The concept of combining ability was developed by Sprague and Tatum (1942). According to them, general combining ability (GCA) measures the average performance of a line in cross combinations while specific combining ability (SCA) measures the deviation of certain expected combinations on the basis of average performance of the lines involved. The combining ability analyses also provide information about the nature and magnitude of gene action involved in the expression of various quantitative characters. Keeping all this in view, the present investigation on combining ability analysis for seed yield and its attributes in Indian mustard [Brassica juncea (L.) Czern \& Coss] was undertaken with the objective to estimate the general and specific combining ability effects and variances.

\section{MATERIALS AND METHODS}

The experimental material for the present investigation consisted of five Mori based CMS lines as female parent (SKM 301, SKM 9928, GM 1, Kranti and GM 2) and seven Mori based restorer lines as male parent (Vardan, Rohini, SKM 319, SKM 303, Pusa Agrani, PCR 7 and

Corresponding author Email: pateljignesh212@gmail.com, ${ }^{1-5}$ Department of Genetics \& Plant Breeding, C.P. College of Agriculture, ${ }^{2}$ Department of Seed Technology, ${ }^{3}$ Castor-Mustard Research Station, S. D. Agricultural University, Sardarkrushinagar ${ }^{4}$ Seed Spices Research Station, S. D. Agricultural University, Jagudan, Gujarat, India 
Mori ' $R$ ' 1-18). Five lines were crossed with seven testers in line $x$ tester mating design during rabi 2017-18 to obtain $35 \mathrm{~F}_{1}$ hybrids of Indian mustard. At the same time, male sterile lines (A lines) were crossed with its maintainer lines ( $B$ line) to get seeds of female parents for evaluation in the next season and the testers or restorer lines (male parents) were selfed to get pure seeds. Female line is CMS, so hand emasculation is not necessary while hybridization was carried out by manual hand pollination. During rabi 2018-19, a set of 48 genotypes comprising of twelve parents and their $35 F_{1}$ hybrids along with standard check GDM 4 were sown in randomized block design with three replications at Castor-Mustard Research Station, S. D. Agricultural University, Sardarkrushinagar. Sardarkrushinagar is situated at semi-arid region of North Gujarat. Geographically, it is situated at $24^{\circ} .31^{\prime} \mathrm{N}$ latitude and $72^{\circ} .32^{\prime} \mathrm{E}$ longitude with an altitude of 154.52 meters above the mean sea level. The soil of the experimental field was sandy loam with pH 7.5. Each treatment was planted in one row, of $3 \mathrm{~m}$ length and $45 \mathrm{~cm}$ apart, plant to plant distance was maintained $15 \mathrm{~cm}$ by thinning. The recommended agronomical practices and plant protection measures were adopted as per requirement. The observations were recorded on five randomly selected plants from each replication for all the traits viz., plant height $(\mathrm{cm})$, total number of branches per plant, total number of siliquae per plant, length of siliqua $(\mathrm{cm})$, number of seeds per siliqua, seed yield per plant (g), 1000 seed weight (g) and oil content (\%) except days to flowering and days to maturity which were recorded on plot basis. Final mean data pertaining to various characters were analyzed as per the procedure of RBD. The combining ability analysis was performed for a Line $\mathrm{x}$ Tester mating design as per the method suggested by Kempthorne (1957). The oil content of each samples were estimated in percentage by using Nuclear Magnetic Resonance (NMR) Technique (Tiwari et al. 1974).

\section{RESULTS AND DISCUSSION}

The analysis of variance for combining ability revealed that the mean square due to females (lines) was significant for all the characters under study except number of seeds per siliqua, seed yield per plant, 1000 seed weight and oil content (Table 1).

Table 1: Analysis of variance (Mean sum of square) for combining ability and estimates of components of variance for ten characters in Indian mustard

\begin{tabular}{|c|c|c|c|c|c|c|c|c|c|c|c|}
\hline $\begin{array}{l}\text { Source of } \\
\text { variation }\end{array}$ & d.f & $\begin{array}{c}\text { Days to } \\
\text { flowering }\end{array}$ & $\begin{array}{l}\text { Days to } \\
\text { maturity }\end{array}$ & $\begin{array}{l}\text { Plant } \\
\text { height }\end{array}$ & $\begin{array}{c}\text { Total } \\
\text { number of } \\
\text { branches } \\
\text { per plant }\end{array}$ & $\begin{array}{c}\text { Total } \\
\text { number of } \\
\text { iliquae per } \\
\text { plant }\end{array}$ & $\begin{array}{l}\text { Siliqua } \\
\text { length }\end{array}$ & $\begin{array}{c}\text { Number } \\
\text { of seeds } \\
\text { per } \\
\text { siliqua }\end{array}$ & $\begin{array}{l}\text { Seed } \\
\text { yield } \\
\text { per } \\
\text { plant }\end{array}$ & $\begin{array}{c}1000 \\
\text { seed } \\
\text { weight }\end{array}$ & $\begin{array}{c}\text { Oil } \\
\text { content }\end{array}$ \\
\hline innc & 2 & & & 36.20 & 130 & 373.92 & 0.02 & 1.12 & 0.28 & 0.02 & 0.07 \\
\hline & 19 & & & & & & & & & & $40^{* *}$ \\
\hline & 4 & & & & & & & & & & \\
\hline & 3 & & & & & 349 & & & 190 & .30 & 0.48 \\
\hline Fema & 12 & $6.28^{*}$ & $5.99^{*}$ & 287.36 & $26.85^{\star \star}$ & $5946.74^{* *}$ & $0.79^{* *}$ & $5.68^{* *}$ & $121.87^{\star * *}$ & * $1.29^{* *}$ & $1.09^{* *}$ \\
\hline Error & 38 & & & & & & 0.05 & 0.75 & 11.18 & 0.02 & 0.14 \\
\hline$\sigma^{2}$ Females & & $4.13^{* *}$ & $1.88^{*}$ & 122. & 7.5 & 160 & $0.22^{*}$ & 0.74 & 4.01 & 0.14 & 0.24 \\
\hline$\sigma^{2}$ Males & & $1.89^{*}$ & & & $10.31^{*}$ & $2266.95^{*}$ & 0.03 & 0.24 & 10.08 & 0.02 & 0.02 \\
\hline & & & & & & 1973 & & & & & $0.12^{*}$ \\
\hline & & 1.3 & & & 7.9 & 1678 & $0.25^{\star \star}$ & $1.48^{* *}$ & $56.44^{* *}$ & $0.42^{*}$ & $0.32^{* *}$ \\
\hline$x^{2}$ & & 2.16 & & 1.75 & 1.14 & 1.18 & 0.48 & 0.31 & 0.14 & 0.17 & 0.38 \\
\hline
\end{tabular}

This indicated significant contribution of females towards general combining ability variance component for these traits. The variance due to males (tester) was significant for the days to flowering, total number of branches per plant and total number of siliquae per plant. The line $x$ tester interaction was significant for all the characters except plant height. This indicates 
significant contribution of hybrids for specific combining ability variance component. The variance component due to females was higher than that of males for days to flowering, days to maturity, plant height, siliqua length, number of seeds per siliqua, 1000 seed weight and oil content. The ratio of $\sigma^{2} \mathrm{gca} / \sigma^{2}$ sca below than unity for days to maturity, siliqua length, number of seeds per siliqua, seed yield per plant, 1000 seed weight and oil content which suggested greater role of non-additive gene action in the inheritance of these traits. The presence of predominantly large amount of non-additive gene action it must be required to maintain heterozygosity in the population. These results are in accordance with the findings of Meena et al. (2017), Rashmi et al. (2018) and Thanmichon et al. (2018). Whereas, the ratio of $\sigma^{2} \mathrm{gca} / \sigma^{2} \mathrm{sca}$ found more than unity for days to flowering, plant height, total number of branches per plant and total number of siliquae per plant which suggested greater role of additive gene action in the inheritance of these traits. The above results are in agreement with the results of Kumar et al.
(2017), Dahiya et al. (2018) and Shrimali et al. (2018).

\section{General combining ability}

The perusal of data (Table 2) revealed that none of the parents was identified good general combiner for all the characters under study. Among the parents, line SKM 9928 was good general combiner for seed yield per plant, total number of branches per plant, siliqua length, number of seeds per siliqua and total number of siliquae per plant; Kranti was good general combiner for total number of branches per plant, total number of siliquae per plant, seed yield per plant and 1000 seed weight, while GM 2 was good general combiner for days to flowering, days to maturity, plant height and oil content. Whereas tester Mori 'R' 1-18 was good general combiner for seed yield per plant, total number of branches per plant and total number of siliquae per plant. Present results are in concurrence with those of Meena et al. (2015).

Table 2: Estimation of general combining ability (GCA) effects of parents for various characters in Indian mustard

\begin{tabular}{|c|c|c|c|c|c|c|c|c|c|c|c|}
\hline & Parents & $\begin{array}{c}\text { Days to } \\
\text { flowering }\end{array}$ & $\begin{array}{l}\text { Days to } \\
\text { maturity }\end{array}$ & $\begin{array}{l}\text { Plant } \\
\text { height }\end{array}$ & $\begin{array}{l}\text { Branches } \\
\text { per plant }\end{array}$ & $\begin{array}{c}\text { Siliquae } \\
\text { per } \\
\text { plant }\end{array}$ & $\begin{array}{l}\text { Siliqua } \\
\text { length }\end{array}$ & $\begin{array}{l}\text { Seeds } \\
\text { per } \\
\text { siliqua }\end{array}$ & $\begin{array}{c}\text { Seed } \\
\text { yield pe } \\
\text { plant }\end{array}$ & $\begin{array}{c}1000 \\
\text { seed } \\
\text { weight }\end{array}$ & $\begin{array}{c}\text { Oil } \\
\text { content }\end{array}$ \\
\hline \multirow{5}{*}{ Lines } & & 0483 & 0.400 & $11.517^{* *}$ & -0.240 & .11 .620 & $0.229^{\star \star}$ & 0.513 & $-2.250^{*}$ & $-0.496^{* *}$ & -0.104 \\
\hline & SKN & & & & & $7^{* *}$ & & & $5.049^{\star *}$ & & \\
\hline & & & & & & & & & -4.2 & & $0^{* *}$ \\
\hline & & & & & & & & & $3.140^{* *}$ & & \\
\hline & & & & & & & & $-0.787^{*}$ & -1.728 & & \\
\hline \multirow{6}{*}{ Testers } & & & & & & & & 0.320 & 0.861 & 0.039 & \\
\hline & SKM 303 & & & & & $-45.683^{* *}$ & & 0.130 & $-3.449^{\text {** }}$ & & \\
\hline & & 0.500 & -0.017 & $7.750^{*}$ & $-1.283^{* *}$ & $-22.923^{* *}$ & $0.165^{\star \star}$ & 0.383 & -0.878 & 0.014 & -0.025 \\
\hline & PCR 7 & -0.567 & -0.083 & $-9.583^{\star *}$ & 0.250 & 2.543 & $-0.234^{* *}$ & $-0.830^{* *}$ & -0.653 & $0.186^{* *}$ & -0.127 \\
\hline & $\begin{array}{c}\text { Mori 'R' }{ }^{2} \text { 1- } \\
18\end{array}$ & $-1.633^{* *}$ & -0.817 & -0.717 & $4.343^{* *}$ & $66.063^{* *}$ & -0.067 & 0.317 & $4.979^{* *}$ & -0.053 & -0.109 \\
\hline & S.Em. \pm & 0.387 & 0.427 & 3.194 & 0.450 & 7.798 & 0.052 & 0.286 & 0.770 & 0.035 & 0.095 \\
\hline
\end{tabular}

\section{Specific combining ability}

Out of thirty five crosses, fifteen crosses were sterile in both the study, pollen fertility $(0 \%)$ and siliquae set per cent $(0 \%)$ so, these fifteen sterile crosses were not considered for the estimation combining ability. The specific combining ability effects of crosses are presented in Table 3. Based on high SCA effect hybrids SKM $301 \times$ SKM 303, SKM $9928 \times$ Pusa Agrani and Kranti $x$ Mori 'R' 1-18 were identified as best specific cross combination for seed yield per plant. Thus, they were good hybrid combinations, contributing towards higher seed yield. The cross SKM $301 \times$ SKM 303 (-2.333) exhibited significant negative SCA effect for days to maturity. The hybrids viz., SKM $9928 \times$ Pusa Agrani (4.633), GM 2 x Mori 'R' 1-18 (3.290), 
SKM 301 x PCR 7 (2.800) and Kranti x SKM 303 (2.693) were good specific combiners for total number of branches per plant and total number of siliquae per plant. Therefore, considered as good specific combiners for total number of branches and siliquae per plant. The six hybrids namely, SKM 9928 x SKM 303 (0.639), GM 2 x Pusa Agrani (0.623), SKM $9928 \times$ Pusa Agrani (0.397), GM 1 x PCR 7 (0.392), Kranti x PCR 7 (0.349) and SKM $301 \times$ Mori 'R' 1-18 (0.289) were exhibited significant positive SCA effects for siliqua length therefore, they were good hybrid combinations contributing towards more siliqua length. The three hybrids i.e., SKM $301 x$ Mori 'R' 1-18 (1.767), GM 2 x Pusa Agrani (1.533) and SKM 9928 x SKM 303 (1.403) were recorded significant positive SCA effects for number of seeds per siliqua. Thus, these three hybrids were considered as good specific combiners for contributing towards more number of seeds per siliqua.

Table 3: The estimates of specific combining ability (SCA) effects for various characters in Indian mustard

\begin{tabular}{|c|c|c|c|c|c|c|c|c|c|c|}
\hline Crosses & $\begin{array}{c}\text { Days to } \\
\text { flowering }\end{array}$ & $\begin{array}{l}\text { Days to } \\
\text { maturity }\end{array}$ & Plant & $\begin{array}{l}\text { Branches } \\
\text { per plant }\end{array}$ & $\begin{array}{c}\text { Siliquae } \\
\text { per } \\
\text { plant }\end{array}$ & $\begin{array}{l}\text { Siliqua } \\
\text { length }\end{array}$ & \begin{tabular}{|c|} 
Seeds \\
per \\
siliqua
\end{tabular} & $\begin{array}{c}\text { Seed } \\
\text { yield per } \\
\text { plant }\end{array}$ & $\begin{array}{c}1000 \\
\text { seed } \\
\text { weight }\end{array}$ & $\begin{array}{c}\text { Oil } \\
\text { content }\end{array}$ \\
\hline SKM 301 x SKM 303 & -1.283 & $-2.333^{*}$ & 8.950 & & 5.900 & 0.219 & 1.087 & $7.165^{\star *}$ & $1.219^{\star \star}$ & -0.097 \\
\hline SKM & & & & & -28.927 & & ${ }^{\star} 1.833^{\star \star}$ & & $-0.863^{* \star}$ & \\
\hline & & & & & 39.6 & & -1.020 & & & \\
\hline SKM & & & & & & & $1.767^{\star \star}$ & & $-0.379^{* *}$ & $64^{*}$ \\
\hline SKN & & & & & & & ${ }^{*} 1.403^{*}$ & -0.531 & $0.160^{*}$ & \\
\hline SKM 9928 & 0.917 & -0.233 & 3.417 & & 73.92 & & -0.250 & $4.739^{* *}$ & -0.032 & 0.017 \\
\hline SKM 9 & -0.68 & 0.5 & -3.2 & & & -0.9 & * $-1.370^{*}$ & -1.273 & 0.093 & -0.3 \\
\hline SKM $\subseteq$ & & & 2.2 & & -43.3 & & 0.217 & -2.935 & $-0.221^{* \star}$ & \\
\hline & & & & & 27.3 & & -0.397 & -3.123 & $-1.221^{* *}$ & $5^{\star *}$ \\
\hline & & & & & & & 0.283 & & & -0. \\
\hline & & & & & 4.2 & & 1.097 & 2.954 & 0.146 & \\
\hline & & & & & $-26 . \varepsilon+r-1-\gamma$ & & -0.983 & -2.331 & $0.298^{* *}$ & \\
\hline & & & & & 36. & & -0.147 & 0.315 & $-0.388^{* \star}$ & \\
\hline Krar & & & & & & & 0.267 & -1.849 & $0.321^{* *}$ & \\
\hline & & & & & & & 0.480 & -2.271 & & \\
\hline Kral & & & & & & & -0.600 & $3.805^{*}$ & $0.305^{\star *}$ & $1^{\text {** }}$ \\
\hline & & & & & -23. & & $1.947^{\star *}$ & $-3.827^{*}$ & $0.231^{\star *}$ & \\
\hline GM 2 x Pusa Agrani & & & 12.0 & & & $0.623^{* *}$ & $1.533^{*}$ & 2.426 & $-0.204^{*}$ & 0.325 \\
\hline & & & & & & & & & & \\
\hline & & & & & 47.0 & & -0.400 & 1.976 & -0.004 & \\
\hline & 0.866 & 0.954 & 7.142 & 1.006 & 17.437 & 0.115 & 0.640 & 1.722 & 0.0784 & 0.213 \\
\hline
\end{tabular}

The seven crosses viz., SKM $301 \times$ SKM 303 (1.219), GM 1 x Pusa Agrani (0.778), Kranti x Pusa Agrani (0.321), Kranti x Mori 'R' 1-18 (0.305), GM 1 x Mori 'R' 1-18 (0.298), GM 2 x SKM 303 (0.231) and SKM $9928 \times$ SKM 303 $(0.160)$ recorded significant and positive SCA effects for 1000 seed weight. Hence, these hybrids were considered for bolder seed size. Out of twenty hybrids, four hybrids such as Kranti x PCR 7 (0.914), GM 1 x SKM 303 (0.685), GM 2 x Mori 'R' 1-18 (0.619) and GM 1 $x$ Mori 'R' 1-18 (0.436) exhibited significant positive SCA effects for oil content. Thus, these hybrids were considered as good specific combiners for oil content. The similar results were also reported by Patel et al. (2013), Meena et al. (2015) and Gideon et al. (2015).

Based on above result it can be concluded that line SKM 9928 was good general combiner for seed yield per plant, total number of branches per plant, siliqua length, number of seeds per siliqua and total number of siliquae per plant and another line Kranti was good general combiner for total number of branches per plant, total number of siliquae per plant, seed yield per plant and 1000 seed weight. Whereas tester Mori 'R' 1-18 was good general combiner for seed yield per plant, total number of 
branches per plant and total number of siliquae per plant. It suggested that these parents might be presumed to be relatively greater number of favorable alleles for developing superior hybrids or varieties of Indian mustard. Based on high SCA effect, hybrids SKM $301 \times$ SKM $303(P \times P)$,

\section{REFERENCES}

Dahiya, N., Bhajan, R., Rashmi and Pant, U. (2018) Heterosis and combining ability for different traits in local germplasm and varietal crosses in Brassica juncea L. International Journal of Chemical Studies 6(1): 1884-1887.

Gideon, J.S., Rangare, N.R., Choudhari, A.K., Kumar, S. and Myrthong, I. (2015) Combining ability analysis for seed yield and component traits in Indian mustard [Brassica juncea (L.) Czern \& Coss.]. Electronic Journal of Plant Breeding 6(2): 445-453.

Kempthorne, O. (1957) An introduction to genetic statistics. New York, John Willey and Sons Inc., New York.

Kumar, A., Tiwari, R., Pandey, P. and Kumar K. (2017) Studies on combining ability and heterosis using cytoplasmic male sterility system in Indian mustard [Brassica juncea (L.) Czern \& Coss]. Electronic Journal of Plant Breeding 8(1): 51-58.

Meena, H., Kumar, S.A., Ram, B., Singh, V.V., Meena, P.D., Singh, B.K. and Singh, D. (2015) Combining ability and heterosis for seed yield and its components in Indian mustard (Brassica juncea L.). Journal of Agricultural Science and Technology 17: 1861-1871.

Meena, H.S., Kumar, A., Kulshrestha, S., Meena, P.D., Ram, B., Sharma, A., Singh, V.V. and Singh, D. (2017) Line $x$ tester analysis for combining ability and heterosis in Indian mustard (Brassica juncea L.). Journal of Oilseed Brassica 8(1): 18-26.

Patel, A.M., Arha, M.D. and Khule, A.A. (2013) Combining ability analysis for seed yield and its attributes in Indian mustard [Brassica juncea (L.) Czern and Coss]. Asian Journal of Bioscience 8(1): 11-14.
SKM $9928 \times$ Pusa Agrani $(G \times P)$ and Kranti $x$ Mori ' $R$ ' 1-18 $(G \times G)$ were identified as best specific cross combination for seed yield per plant. These hybrids need to be tested in multilocation trials for stability analysis.

Rashmi, Dahiya, N., Tufchi, M., Lohani, P., Bhajan, R. and Pant, U. (2018) Studies on heterosis and combining ability for yield and its contributing traits in CMS based hybrids of Brassica juncea $\mathrm{L}$. International Journal of Chemical Studies 6(4): 3347-3351.

Shrimali, T.M., Chauhan, R.M., Prajapati, K.P., Desai, S.A., Patel, J.R., Patel, P.T., Patel, P.J. and Chaudhary, B.K. (2018) Analysis of yield and its components based on heterosis and combining ability in Indian mustard (Brassica juncea L. Czern \& Coss.). International Journal of Pure and Applied Bioscience 6(1): 219224.

Singh, A., Avtar, R., Singh, D., Sangwan, O., Thakral, N.K., Malik, V.S., Goyat, B. and Dalal, U. (2013) Combining ability analysis for seed yield and component traits in Indian mustard [Brassica juncea (L.) Czern and Coss.]. Research in Plant Biology 3(2): 26-31.

Sprague, G.F. and Tatum, L.A. (1942) General versus specific combining ability in single crosses in corn. Agronomy Journal 34: 923-932.

Thanmichon, S., Ullah, Z. and Baruah, P.K. (2018) Combining ability and heterobeltiosis for yield and yield attributing traits in Indian mustard (Brassica juncea L.). Journal of Oilseed Brassica 9(2): 132-138.

Tiwari, P.N., Gambier, P.N. and Rajan, T.S. (1974) Rapid and non-destructive determination of seed oil by Pulsed Nuclear Magnetic Resonance Technique. Journal of American Chemistry Society 51: 104-109. 